\title{
PROLONGED ILEUS WITH ACUTE SPINAL CORD INJURY RESPONDING TO METACLOPRAMIDE
}

\author{
By Freeman Miller, M.D. and Thomas C. Fenzl, M.D. \\ Department of Orthopedics and Rehabilitation, University of Virginia Medical Center, \\ Charlottesville, Virginia, U.S.A.
}

Key words: Spinal Cord Injury; Prolonged ileus; Metoclopramide.

\section{Introduction}

GASTROINTESTINAL malfunction is almost always seen after acute spinal cord injury. As 'spinal shock' resolves, autonomic reflex activity allows the intestines to function again (Guttmann, I973). In most patients the time from acute injury until the intestine functions for nutritional absorption is two to five days. However, those patients who initially have extensive associated pulmonary and septic problems will often have a prolonged period of ileus. During this period they require intravenous hyperalimentation, which slows the physical and especially the psychological rehabilitation.

Metoclopramide, a drug derived from procainamide, has been demonstrated to accelerate gastric emptying without increasing gastric secretion (Jacoby, I967), increases small intestinal motility (Johnson, I97I), and has very little effect on the colon (Pinder, 1976). It has been used effectively to decrease postoperative nausea after abdominal surgery (Pinder, I976 and Davidson, 1979), to increase transit time during gastrointestinal radiological procedures (Lipton, 1977), decrease nausea due to radiation sickness (Pinder, 1976), and increase transit time in gastroparesis diabeticorum (Brady, 1977). It has not been found effective in reducing postoperative adynamic ileus secondary to abdominal procedures (Davidson, 1979), or in treating pseudo-obstruction of the bowel (Lipton, 1977). The side effects of metoclopramide are few, transient, and completely reversible when the drug is stopped. Lassitude, drowsiness, diarrhoea constipation, or dry mouth are reported by Io per cent of patients. Rarely a patient will have an extrapyramidal reaction similar to a phenothiazine reaction, but disappears completely when the drug is stopped (Pinder, I976).

This is the first known report of an acute quadriplegic with prolonged ileus who responded to metoclopramide.

\section{Case History}

A 21-year-old male was involved in a motor vehicle accident on 3 August 1979. The patient only remembers a momentary loss of consciousness and then immediate inability to move his arms and legs. He presented to our emergency room on a back board with his head and neck immobilized. The admission vital signs included a temperature of 34.4 centigrade, blood pressure was 100/70, and pulse was 50 .

Physical examination confirmed the diagnosis of complete $\mathrm{C}_{5}$ quadriplegia. There was no evidence of intra-abdominal trauma. Extensive admission laboratory data was all within normal limits. Roentgenograms on admission showed a fracture dislocation of $\mathrm{C}_{5}$ on $\mathrm{C} 6$ with 25 per cent anterior subluxation of $\mathrm{C} 5$. 
His early hospital course was complicated by bilateral pneumothoraces, pneumonia, urinary tract infections, and generalized sepsis, all treated successfully while the patient was in the intensive care unit. Initially his ileus was treated with nasogastric suction and central hyperalimentation after a negative peritoneal lavage was performed. One week post injury he was noted to have bowel sounds and his nasogastric tube was clamped. Several hours later the patient developed severe nausea and vomiting, increasing gastric residuals, and abdominal distention. The patient's laboratory data remained essentially normal and plain roentgenograms of the abdomen showed only gastric distension. Trials with digital stimulation, Dulcolax tablets, rectal suppositories, and high enemas all were without results. Barium studies were withheld because of the ileus, but abdominal ultrasound and an abdominal CT scan were performed, both of which were negative. Endoscopy revealed a normal esophagus, stomach and upper duodenum. He was started on subcutaneous urecholine to stimulate gastrointestinal motility, but this was stopped subsequently due to side effects and without change of the ileus.

At 12 weeks post injury the patient was started on intravenous metoclopramide. Initially the stomach was emptied via the nasogastric tube and metoclopramide was given Io $\mathrm{mg}$ intravenously over a I minute period along with $200 \mathrm{ml}$ of clear liquid administered as a test meal. Residuals were checked at I hour and 4 hours after the metoclopramide. This was well tolerated and on the second day the nasogastric tube was removed and metoclopramide was given on a twice-a-day schedule followed by $30 \mathrm{ml}$ of clear liquids every hour for five hours. This was tolerated with minimal nausea and the feeding volumes were increased to $100 \mathrm{ml}$ by the third day and to $250 \mathrm{ml}$ of full liquids at the end of seven days. At this point radionucleotide-labelled oatmeal was given to test gastrointestinal motility without metoclopramide. $200 \mathrm{ml}$ of oatmeal was given, and approximately 15 minutes later the patient had severe nausea and vomiting. Isotope scan revealed little activity in the stomach and none past the pylorus. He was returned to his room and Io $\mathrm{mg}$ of metoclopramide was given, followed by $200 \mathrm{ml}$ of full liquid diet, which the patient tolerated without nausea.

Hyperalimentation was slowly weaned as the patient assumed a high calorie, high protein diet. At I4 weeks post injury he was started on oral metoclopramide $10 \mathrm{mg} 30$ minutes prior to each meal. This regimen was well tolerated, with only minimal nausea, which was found to abate when he was given additional food when the nausea started. At 17 weeks post injury the metoclopramide was reduced to five $\mathrm{mg}$ and was totally stopped at 19 weeks post injury. Nausea and vomiting was not noted after cessation of the metoclopramide, and a followup abdominal CT scan was negative.

The only side effects of metoclopramide were dyspepsia, diarrhoea, some minor lethargy, and somnolence. The former were managed with oral Maalox 30 cc every four hours and Metamucil $15 \mathrm{ml}$ three times a day, the latter decreased gradually over the first three weeks of metaclopramide therapy.

\section{Discussion}

In the case presented, although the patient had multiple problems, his persistent ileus was the main factor slowing his rehabilitation. The ileus responded to intravenous followed by oral metoclopramide. This case indicates that metoclopramide should be studied further as a means of reducing the ileus associated with acute spinal cord injury, and may be especially useful in those patients with prolonged ileus.

\section{SUMMARY}

This is a case report of an acute C- 5 complete quadriplegic with prolonged ileus. The ileus resolved only after the administration of metoclopramide. Metoclopramide is a drug that increases gastrointestinal motility, has few significant side effects, and may be of use in decreasing the ileus associated with acute spinal cord injuries. 


\section{RÉSUMÉ}

Ceci est un dossier médical d'un C-5 quadruplégique, complète et aiguë, avec l'iléus étendu. L'iléus s'est résolu seulement après l'administration du métoclopramide. Le métoclopramide est une drogue qui fait augmenter la motilité gastrointestinale, qui a peu d'effets secondaires, et qui peut-être utilisée en diminuant l'iléus qui s'est associé aux blessures du cordon médullaire.

\section{ZUSAMMENFASSUNG}

Die ist ein Fallbericht einer akuten kompletten C-5 Quadriplegie mit protraktiertem Ileus. Der Ileus löste sich mit nach der Verabreichung von Metaclopramide. Meta clopramide ist ein Arzneimittel, das die gastrointestinale Motilität steigert, wenig signifikante Nebenwirkungen hat und von Nutzen sein mag bei der Verminderung des Ileus, der mit akuten Rückenmarksverletzungen einhergeht.

\section{REFERENCES}

BRAdy, P. G. \& RichaRdson, R. (1977). Gastric bezoar formation secondary to gastroparesis diabeticorum. Archives of Internal Medicine, 137, 1729.

Davidson, E. D., Hersh, T., Brinner, F. A., Barnett, S. M. \& Boyle, L. P. (I979). The effects of metoclopramide on postoperative ileus. Annals of Surgery, 190, 27-30.

Guttmann, L. (1973). Spinal Cord Injuries-Comprehensive Management and Research, pp. 43-445, Blackwell Scientific Publications, Oxford.

JACOBY, H. I. \& BRODIE, D. A. (I967). Gastrointestinal actions of metoclopramide: An experimental study. Gastroenterology, 52, 676-684.

Johnson, A. G. (I97I). The action of metoclopramide on human gastroduedoenal motility. Gut, I2, $42 \mathrm{I}-426$.

Lipton, A. B. \& Knauer, C. M. (1977). Pseudo-obstruction of the bowel-therapeutic trial with metoclopramide. Digestive Diseases, 22, 263-265.

Pinder, R. M., Brogden, R. N., SAwyer, P. R., Speight, T. M. \& Avery, G. S. (1976). Metoclopramide: A review of its pharmacological properties and clinical use. Drugs, 12, 8I-I3I. 